\title{
Maternal methylenetetrahydrofolate reductase (MTHFR) gene A1298C polymorphism and risk of nonsyndromic Cleft lip and/or Palate (NSCL/P) in offspring: A meta-analysis
}

\author{
Vandana Rai ${ }^{1}$ \\ ${ }^{1}$ Human Molecular Genetics Laboratory, Department of Biotechnology, VBS Purvanchal University, Jaunpur-222001, Uttar Pradesh, India
}

\section{A B S T R A C T}

Objective: Methyleneterahydrofolate reductase (MTHFR) A1298C polymorphism has been reported a risk factor for nonsyndromic cleft/palate (NSCL/P) in several published articles but results were inconclusive. To confirm the association between maternal MTHFR A1298C polymorphism and NSCL/P risk, a meta-analysis was conducted. Method: Case control articles for maternal MTHFR A1298C polymorphism and NSCL/P risk were identified by search of databases including PubMed, Google Scholar, Elsevier and Springer Link for the period up to December, 2013. Odds ratios (ORs) with $95 \%$ confidence intervals (Cls) were estimated to assess the association. Results: Meta-analysis of ten included studies showed that there was no significant association between maternal MTHFR A1298C polymorphism and risk of NSCL/P under five genetic models (for $C$ versus $A$, $O R=1.007,95 \% \mathrm{Cl}=0.89-1.13$, $P=0.90$; for $C C$ versus $A A, O R=0.851,95 \% C l=0.63-1.15, P=0.30$; for $A C$ versus $A A, O R=1.033,95 \% C l=0.88-1.21, P=0.69$; for $C C+A C$ versus $A A, O R=1.005$, $95 \% \mathrm{Cl}=0.86-1.17, \mathrm{P}=0.94$; for $\mathrm{CC}$ versus $\mathrm{AC}+\mathrm{AA}, \mathrm{OR}=0.86,95 \% \mathrm{Cl}=0.64-1.15$, $\mathrm{P}=0.32$ ). Conclusion: In conclusion, results of present meta-analysis demonstrate that maternal MTHFR A1298C polymorphism may not be a risk factor for developing NSCL/P in offspring. Further studies with large sample sizes are needed to evaluate the association of maternal MTHFR A1298C polymorphism with NSCL/P in more detail.

Key words: Homocysteine, Orofacial cleft, Cleft lip/palate, Methylenetetrahydrofolate reductase, MTHFR, A1298C

\section{INTRODUCTION}

Nonsyndromic cleft lip with or without cleft palate (NSCL/P)(OMIM 119530) is one of the most common congenital malformation with the global prevalence ranging between 1 in 300 and 1 in 2000 depending upon geographical origin, ethnicity, and socioeconomic status. ${ }^{1}$ The frequency of NSCL/P has been found to decrease in the offspring of mothers who have received prenatal dietary supplementation with multivitamins, ${ }^{2-6}$ suggesting that one or more vitamins may be of importance in the pathogenesis or prevention of NSCL/P. The effectiveness of maternal folic acid supplementation during pregnancy
Access this article online

Website:

http://nepjol.info/index.php/AJMS 
10-methylenetetrahydrofolate to 5-methylenetetrahydrofolate reductase, which donates methyl group for the conversion of homocysteine to methionine. The methyl cycle supplies 1-carbon units critical for a variety of methylation reactions essential for proper gene expression and maternal and paternal imprinting by methylated DNA. The human MTHFR gene is $20 \mathrm{~kb}$ long $(20,336 \mathrm{bp})$ and mapped at 1p36.3 (OMIM 607093), having 11 exons. Several single nucleotide polymorphisms (SNPs) in the MTHFR gene have been identified. Among which the most commonly studied polymorphisms are C677T in exon 4 and A1298C in exon 7.,10 These two polymorphisms were shown to be associated with reduced enzyme activity.

A1298C allele frequency differs greatly in various ethnic groups of the world. The prevalence of the A1298C homozygote variant genotype ranges from 7 to $12 \%$ in White populations from North America and Europe. Lower frequencies have been reported in Hispanics (4 to $5 \%$ ), Chinese (1 to $4 \%$ ) and Asian populations (1 to $4 \%) .{ }^{11,12}$ Several studies have explored the impact of maternal MTHFR A1298C polymorphism NSCL/P, but the association is conflicting. ${ }^{13-17}$ To better understand these issues, a comprehensive meta-analysis was conducted to clarify the quantitative association between the maternal MTHFR A1298C polymorphism and risk of NSCL/P.

\section{METHODS}

\section{Article search}

Comprehensive search was conducted in the Pubmed, Google Scholar, Elsevier and Springer Link databases from their inception through December, 2013. Following search terms were used: 'MTHFR', 'A1298C', 'methylenetetrahydrofolate reductase', 'polymorphism', 'Cleft lip', and Cleft palate' and 'NSCL/P'. There was no language limitation. All references cited in those included studies were also reviewed to identify additional published articles not indexed in common databases.

Inclusion criteria were following: (1) study should be published in a peer-reviewed journal; (2) studies had sufficient data to calculate the odds ratio (OR) with a confidence interval (CI) and a P-value, (3) study should be case control, (4) should used the relevant genotyping protocols or provided reference to them, (5) used healthy individuals as controls. The major reasons for exclusion of studies were (1) only case studies, (2) review, conference abstract, letter to editor and editorials, and (3) containing overlapping data.

\section{Data extraction}

Information was carefully extracted from all eligible studies according to the inclusion criteria listed above.
The following data were collected from each study: first author's family name, year of publication, country, ethnicity, genotyping method, sample size, and numbers of genotype A1298C for both cases and controls, respectively.

\section{Statistical analysis}

In the meta-analysis of MTHFR A1298C polymorphism, the overall association of the $\mathrm{C}$ allele with risk of NSCL/P was evaluated in comparison with the $\mathrm{A}$ allele (Allele contrast model). Also, the contrasts of homozygote $\mathrm{CC}$ versus AA (homozygote model), AC versus AA (co-dominant model), $\mathrm{CC}$ versus $\mathrm{AC}+\mathrm{AA}$ (recessive model) and $\mathrm{CC}+\mathrm{AC}$ versus $\mathrm{AA}$ (dominant model) were examined.

The associations were indicated as a pooled odds ratio (OR) with the corresponding 95\% confidence interval (CI). The heterogeneity between studies was tested using the Q-statistic, which is a weighted sum of the squares of the deviations of individual study OR estimates from the overall estimate. ${ }^{18,19}$ When the ORs are homogeneous, Q follows a chi-squared distribution with $r-1$ ( $r$ is the number of studies), degrees of freedom ( $\mathrm{df}$ ). When $\mathrm{P}<0.50$ then the heterogeneity was considered to be statistically significant. Heterogeneity was quantified with the $\mathrm{I}^{2}$ metric $\left(\mathrm{I}^{2}=(\mathrm{Q}-\mathrm{df}) / \mathrm{Q}\right)$, which is independent of the number of studies in the meta-analysis. $\mathrm{I}^{2}$ takes values of between 0 and $100 \%$, with higher values denoting a greater degree of heterogeneity. ${ }^{19,20}$ The pooled OR was estimated using fixed effects $(\mathrm{FE})^{21}$ and random effects (RE) ${ }^{22}$ models. Random effects modeling assume a genuine diversity in the results of various studies, and it incorporates a between-study variance into the calculations. Hence, when there is heterogeneity between studies then the pooled OR is preferably estimated using the RE model. ${ }^{19,23}$

\section{Publication bias}

Funnel plots were drawn to estimate the publication bias, in which the standard error (SE) of $\log (\mathrm{OR})$ of each study and precision of $\log (\mathrm{OR})$ of each study were plotted against its $\log (\mathrm{OR})$. The funnel plot asymmetry was assessed with Egger's test. ${ }^{24}$ Publication bias $\mathrm{P}<0.05$ was considered statistically significant. All analyses were performed using the computer program MIX version 1.7.25 A p value less than 0.05 was considered statistically significant, and all the $\mathrm{p}$ values were two sided.

\section{RESULTS}

\section{Study characteristics}

Details of the included studies were given in table 1. Total ten studies were found to be suitable for the inclusion in the present meta-analysis. ${ }^{13-17,26-30}$ All these ten studies were performed in different countries- Argentina, ${ }^{26}$ India, ${ }^{16}$ Norway, ${ }^{13}$ Ireland, ${ }^{15}$ Italy, ${ }^{14}$ Netherlands, ${ }^{28}$ Thailand, ${ }^{27}$ 
Ukraine, ${ }^{29}$ Turkey, ${ }^{30}$ and Venezuela. ${ }^{17}$ In one study ${ }^{16}$ reported only allele numbers (Table 1). In only seven studies $^{13,14,17,27-30}$ odds ratio was above one.

\section{Summary statistics}

The frequencies of the genotypes MTHFR 1298AA and $1298 \mathrm{AC}$ were the highest in both cases and controls, and allele $\mathrm{A}$ was the most common (Table 2). The prevalence of allele $\mathrm{C}$ was $26.48 \%$ and $31.99 \%$ for the CL/P case mothers and control groups, respectively. The percentage frequency of CC genotype among case mothers and controls was $6.77 \%$ and $10.29 \%$, respectively whereas prevalence of AC heterozygote among case mothers was $39.84 \%$ and $43.43 \%$ in controls. The prevalence of AA homozygote among CL/P case mothers and controls was $53.39 \%$ and $46.28 \%$, respectively. In all the studies, distribution of genotypes in the control group was in Hardy Weinberg Equilibrium.

\section{Meta-analysis}

Mutant allele (C) did not show any significant association with NSCL/P in both fixed effect $(\mathrm{p}=0.90, \mathrm{OR}=1.007$, $95 \%$ CI $=0.89-1.13)$ and random effect $(\mathrm{p}=0.90$, $\mathrm{OR}=1.007,95 \%$ CI $=0.89-1.13$ ) $\operatorname{model}$ (Figure 1 ). In cumulative analysis using fixed and random effect models, the association of mutant ' $\mathrm{C}$ ' allele with NSCL/P remained insignificant statistically with the addition of each study. Odds ratio for mutant genotypes $(\mathrm{CC}+\mathrm{AC})$ showed no association with NSCL/P adopting both fixed ( $\mathrm{p}=0.94, \mathrm{OR}=1.005,95 \% \mathrm{CI}=0.86-1.117)$ and random $(\mathrm{p}=0.94, \mathrm{OR}=1.005,95 \% \mathrm{CI}=0.86-1.17)$ effect models. Similarly no significant association was found with other three genetic models (for CC vs AA: OR $=0.851,95 \%$ $\mathrm{CI}=0.63-1.15, \mathrm{p}=0.30$; for $\mathrm{AC}$ vs $\mathrm{AA}: \mathrm{OR}=1.03,95 \%$ $\mathrm{CI}=0.88-1.21, \mathrm{p}=0.69$; for $\mathrm{CC}$ vs $\mathrm{AC}+\mathrm{AA}: \mathrm{OR}=0.86$, $95 \% \mathrm{CI}=0.64-1.15, \mathrm{p}=0.32)($ Table 3$)$.

\section{Publication bias}

Publication bias could not be observed in all five genetic models by using of Begg's and Egger's test. P values of Egger's test were insignificant in all five models (for $\mathrm{C}$ vs A (allele contrast model): $\mathrm{p}=0.34$; for $\mathrm{CC}$ vs AA (homozygote model): $\mathrm{p}=0.34$; AC vs AA(co-dominant model): $\mathrm{p}$ value $=0.99$; for $\mathrm{CC}+\mathrm{AC}$ vs $\mathrm{AA}($ dominant model $)$ : $\mathrm{p}=0.69$; For $\mathrm{CC}$ vs $\mathrm{AC}+\mathrm{AA}$ (recessive model): $\mathrm{p}=0.44$ ). Funnel plots were showed in Figure 2 and all funnel plots were symmetrical.

\section{DISCUSSION}

There is considerable evidence suggesting that folate related genes play a role in the etiology of nonsyndromic facial clefts. Nonsyndromic clefts are complex traits and it is likely that genetic factors interact with environmental

\begin{tabular}{|c|c|c|c|c|c|}
\hline Study & Country & Year & Case & Control & References \\
\hline Tolarova et al. & Argentina & 1998 & 108 & 103 & Am J Hum Genet, 63:A27. \\
\hline Shoteresuk et al. & Thailand & 2003 & 109 & 202 & J Med Genet, 40:e64. \\
\hline Van Roij et al. & The Netherlands & 2003 & 94 & 115 & Am J Epidemiol, 157:583-591. \\
\hline Nurk et al. & Norway & 2004 & 22 & 14452 & Am J Med 117: 26-31. \\
\hline Pezzetti et al. & Italy & 2004 & 110 & 289 & Hum Mutat, $24: 104-105$. \\
\hline Mills et al. & Ireland & 2008 & 407 & 1050 & Birth defects research, 82:636-643. \\
\hline Ali et al. & India & 2009 & 323 & 214 & Genetic Testing and Molecular Biomarkers, 13 (3). \\
\hline Sozen et al. & Venezuela & 2009 & 179 & 138 & J. Genet. Genomics, 36: 283-288. \\
\hline Chorna et al. & Ukraine & 2011 & 33 & 50 & Cytology and Genetics, 45: 177-181. \\
\hline Semic-Jusufagic et al. & Turkey & 2012 & 56 & 76 & The Turkish Journal of Pediatrics, 54: 617-625 \\
\hline
\end{tabular}

\begin{tabular}{|c|c|c|c|c|c|c|c|c|c|c|}
\hline \multirow[t]{3}{*}{ Study ID } & \multicolumn{6}{|c|}{ Genotype } & \multicolumn{4}{|c|}{ Alleles } \\
\hline & \multicolumn{2}{|c|}{ AA } & \multicolumn{2}{|c|}{ AC } & \multicolumn{2}{|c|}{$\mathrm{CC}$} & \multicolumn{2}{|c|}{ A } & \multicolumn{2}{|c|}{ C } \\
\hline & Case & Control & Case & Control & Case & Control & Case & Control & Case & Control \\
\hline Tolarova et al., 1998 & 56 & 50 & 27 & 25 & 3 & 3 & 139 & 125 & 33 & 31 \\
\hline Shoteresuk et al., 2003 & 30 & 108 & 33 & 80 & 4 & 14 & 93 & 296 & 41 & 108 \\
\hline van Roij et al., 2003 & 57 & 76 & 52 & 67 & 16 & 16 & 166 & 219 & 84 & 99 \\
\hline Nurk et al., 2004 & 9 & 6598 & 10 & 6332 & 3 & 1522 & 28 & 19528 & 16 & 9376 \\
\hline Pezzetti et al., 2004 & 57 & 121 & 36 & 130 & 11 & 38 & 150 & 372 & 58 & 206 \\
\hline Mills et al., 2008 & 179 & 519 & 164 & 439 & 23 & 92 & 522 & 1477 & 210 & 623 \\
\hline Ali et al., 2009 & & & & & & & 175 & 295 & 57 & 133 \\
\hline Sozen et al, 2009 & 119 & 101 & 47 & 33 & 2 & 4 & 285 & 235 & 51 & 41 \\
\hline Chorna et al., 2011 & 12 & 24 & 13 & 22 & 2 & 4 & 37 & 70 & 17 & 30 \\
\hline Semic-Jusufagic et al., 2012 & 25 & 36 & 24 & 36 & 5 & 4 & 74 & 108 & 34 & 44 \\
\hline
\end{tabular}




\begin{tabular}{|c|c|c|c|c|c|}
\hline Genetic models & $\begin{array}{l}\text { Fixed effect } \\
\text { OR }(95 \% \mathrm{Cl}), \mathrm{p}\end{array}$ & $\begin{array}{l}\text { Random effect } \\
\text { OR }(95 \% \mathrm{Cl}), p\end{array}$ & $\begin{array}{l}\text { Heterogeneity } \\
\text { p value ( } Q \text { test) }\end{array}$ & $I^{2}(\%)$ & $\begin{array}{l}\text { Publication bias } \\
\text { (p of Egger's test) }\end{array}$ \\
\hline Allele Contrast (C vs A) & 1.007 (0.89-1.13), 0.90 & $1.0074(0.89-1.13), 0.90$ & 0.73 & 0 & 0.34 \\
\hline Co-dominant (AC vs $A A)$ & $1.0333(0.88-1.21), 0.69$ & $1.0349(0.88-1.21), 0.68$ & 0.49 & 0 & 0.99 \\
\hline Homozygote (CC vs AA) & $0.8515(0.63-1.15), 0.30$ & $0.862(0.63-1.17), 0.34$ & 0.76 & 0 & 0.336 \\
\hline Dominant $(\mathrm{C}+\mathrm{AC}$ vs $\mathrm{AA})$ & 1.005 (0.86-1.17), 0.94 & $1.005(0.86-1.17), 0.94$ & 0.50 & 0 & 0.69 \\
\hline Recessive $(A A+A C$ vs $C C)$ & $0.8605(0.64-1.1546), 0.32$ & $0.8709(0.65-1.17), 0.36$ & 0.80 & 0 & 0.44 \\
\hline
\end{tabular}

\begin{tabular}{|c|c|c|c|c|c|c|c|c|}
\hline Study ID & $\begin{array}{l}\text { Exposed } \\
\text { AM[e]/SE[e] }\end{array}$ & $\begin{array}{l}\text { Control } \\
\text { AM[c]/SE[c] }\end{array}$ & & & & $\begin{array}{l}\text { Weight } \\
(\%)\end{array}$ & & $\begin{array}{l}\text { Association measure } \\
\text { with } 95 \% \mathrm{Cl}\end{array}$ \\
\hline Tolarova et al.,1998 & -0.0410 .28 & $-0.041: 0.28$ & \multirow{10}{*}{ 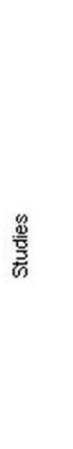 } & & & $4.48 \%$ & 1 & $0.9598(0.5544$ to 1.6616$)$ \\
\hline Shoteresuk et al.,2003 & $0.191 / 0.217$ & $0.191,0.217$ & & 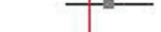 & & $7.46 \%$ & 1 & $1.2105(0.7911$ to 1.8521$)$ \\
\hline van Roij et al.,2003 & 0.1130 .178 & 0.1130 .178 & & - & & $11.08 \%$ & IIII & $1.1196(0.7899$ to 1.587$)$ \\
\hline Nurk et al.,2004 & 0.17410 .315 & 0.1740 .315 & & - & & $3.54 \%$ & 1 & 1.1901 ( 0.6419 to 2.2065 ) \\
\hline Pezzetti et al._2004 & $0.174 / 0.179$ & $0.174 \pi 0.179$ & & - & & $10.96 \%$ & IIII & $1.1901(0.8379$ to 1.6902$)$ \\
\hline Mills et al.,2008 & -0.0510 .096 & -0.05110 .096 & & - - & & $38.11 \%$ & . $\||\||||||||||$ & $0.9503(0.7873$ to 1.147$)$ \\
\hline Ali et al.,2009 & -0.32910 .187 & -0.3290 .187 & & & & $10.04 \%$ & . IIII & $0.7196(0.4988$ to 1.0382$)$ \\
\hline Sozen et al.,2009 & $0.03 / 0.226$ & 0.030 .226 & & L_ & & $6.88 \%$ & 1 & $1.0305(0.6617$ to 1.6047$)$ \\
\hline Chorna et al.,2011 & 0.0680 .356 & 0.0680 .356 & & & & $2.77 \%$ & 1 & $1.0704(0.5327$ to 2.1506$)$ \\
\hline Sermic-Jusuragic et al.,2 & 0.12210 .274 & 0.1220 .274 & & | & & $4.68 \%$ & 1 & $1.1298(0.6603$ to 1.9329$)$ \\
\hline \multirow[t]{3}{*}{ META-ANALYSIS: } & & & & p & & $100 \%$ & 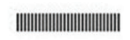 & 1.0074 (0.8969 to 1.1314$)$ \\
\hline & & & \multirow[t]{2}{*}{0.1} & 1 & 10 & & & \\
\hline & & & & OR (log scale) & & & & \\
\hline
\end{tabular}

Figure 1: Forest plots for the association between MTHFR A1298C polymorphism and cleft lip for additive model (C vs A) with Random effect model

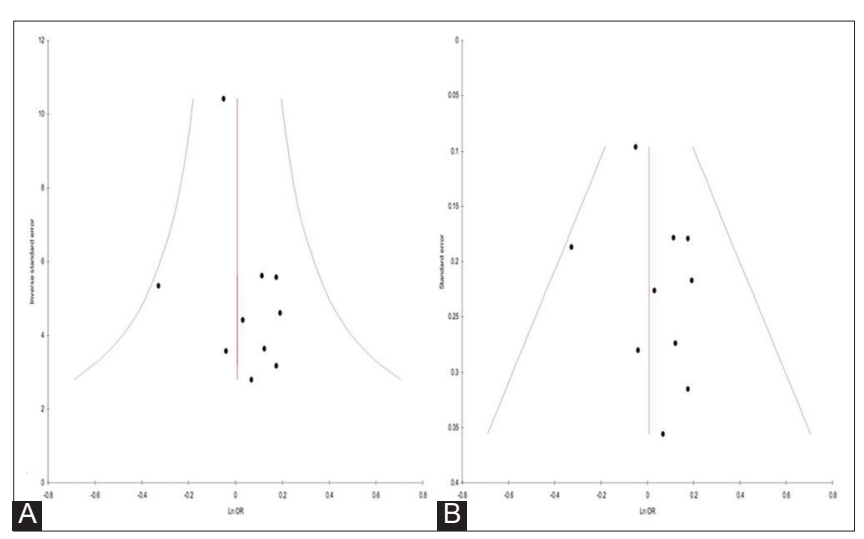

Figure 2: Funnel plots (A) precision versus OR (C vs. A), (B) standard error versus OR ( $C$ vs. $A$ )

factors. Folate has long been considered one such factor in number of observational studies. ${ }^{2-5,7,8,15,31}$ Maternal folic acid supplementation in early pregnancy has been suggested to play a role in the prevention of nonsyndromic orofacial cleft, i.e. cleft lip with or without cleft palate (CL/P).

Martinelli et $a^{32}$ suggested that the variants of the MTHFR gene, considered to be a cause of reduced efficiency of folate utilization, could be an important risk factor for CL/P. Wong et al. ${ }^{33}$ observed that maternal hyperhomocysteinemia may be a risk factor for having $\mathrm{CL} / \mathrm{P}$ offspring. Considering that one of the effects of the reduced MTHFR activity is the hyperhomocysteinemia. Insufficient DNA synthesis and methylation by the mother could damage the developing embryo.

Meta-analysis is a powerful tool for analyzing cumulative data of studies where the individual sample sizes are small and the statistical power low. ${ }^{34}$ Several meta-analysis studies illustrate the utility of the technique in identifying genes of small effects like MTHFR with phenotypes like -NTD, ${ }^{35}$ Down syndrome, ${ }^{36}$ Cardiovascular disease, ${ }^{37}$ Migraine, ${ }^{38}$ Schizophrenia, ${ }^{39}$ bipolar disorder, ${ }^{40}$ and depression. ${ }^{41}$

The present meta-analysis (including 1019 case mothers and 16494 controls) was performed to assess the relationship between MTHFR A1298C polymorphism and NSCL/P with ten published case control studies, but no significant association was found in the total population. The main strength of the present study was that heterogeneity and publication bias were not observed. As with all meta-analyses, present analysis had also several limitations that must be acknowledged. 
Firstly, sample sizes of some included studies are rather small and they do not have adequate power to detect the possible risk for MTHFR A1298C polymorphism. ${ }^{13,29,30}$ Secondly, main analysis was based on unadjusted estimates owing to the lack of adjusted estimates. However, a more precise analysis could be performed if adjusted estimates were available in all studies. Further owing to the limited evidence available on other folate gene polymorphisms; this review was restricted to the only one MTHFR polymorphism. Finally, data were not stratified by folate intake, ethinicity, and other suspected factors. Therefore, a more precise analysis should be conducted if enough data were available.

\section{ACKNOWLEDGMENTS}

The author is highly grateful to Leon Bax (Chief Scientific Officer at BiostatXL, UMC Utrecht) for his valuable suggestions, which help us in statistical analysis.

\section{REFERENCES}

1. Clark JD, Mossey PA, Sharp L and Little J. Socioeconomic status and orofacial clefts in Scotland, 1989 to 1998. Cleft Palate Craniofac J 2003; 40: 481-485.

2. Shaw GM, Lammer EJ, Wasserman CR, O'Malley CD, and Tolarova MM. Risks of orofacial clefts in children born to women using multivitamins containing folic acid periconceptionally. Lancet 1995; 346:393-396.

3. Tolarova M and Harris J. Reduced recurrence of orofacial clefts after periconceptional supplementation with high-dose folic acid and multivitamins. Teratology 1995; 51:71-78.

4. Itikala PR, Watkins ML, Mulinare J, Moore CA and Liu Y. Maternal multivitamin use and orofacial clefts in offspring. Teratology 2001; 63:79-86.

5. Loffredo LC, Souza JM, Freitas JA and Moosey PA. Oral clefts and vitamin supplementation. Cleft Palate Craniofac J 2001; 38:76-83.

6. Wilcox AJ, Lie RT, Solvoll K, Taylor J, McConnaughey DR, Åbyholm F, et al. Folic acid supplements and risk of facial clefts: National population based case-control study. Br Med J 2007; 334: 464.

7. Czeizel AE, Toth M and Rockenbauer M. Population-based case control study of folic acid supplementation during pregnancy. Teratology 1996; 53:345-351.

8. Czeizel AE, Timar $L$ and Sarkozi A. Dose-dependent effect of folic acid on the prevention of orofacial clefts. Pediatrics 1999; 104:e66.

9. Frosst P, Bloom HJ, Milos R, Goyette P, Sheppard CA, Matthews RG, et al. A Candidate Genetic Risk Factor for Vascular Disease: a Common Mutation in Methylenetetrahydrofolate Reductase. Nat Genet 1995; 10: 111-113.

10. Weisberg I, Tran P, Christensen B, Sibani S and Rozen A. A second genetic polymorphism in methylenetetrahydrofolate reductase (MTHFR) associated with decreased enzyme activity. Mol Genet Metab 1998; 64:169-172.

11. Botto LD and Yang Q. 5,10-Methylenetetrahydrofolate reductase gene variants and congenital anomalies: a HuGE review. Am J Epidemiol 2000; 151: 862-877.
12. Robien $\mathrm{K}$ and Ulrich CM. 5,10-Methylenetetrahydrofolate reductase polymorphisms and leukemia risk: a HuGE minireview. Am J Epidemio 2003; 157:571-582.

13. Nurk E, Tell GS, Refsum H, Ueland PM and Vollset SE. Associations between maternal methylenetetrahydrofolate reductase polymorphisms and adverse outcomes of pregnancy: The Hordaland Homocysteine Study. Am J Med 2004; 117: 26-31.

14. Pezzetti F, Martinelli M, Scapoli L, Carinci F, Palmieri A, Marchesini J, et al. Maternal MTHFR Variant Forms Increase the Risk in Offspring of Isolated Nonsyndromic Cleft Lip with Or Without Cleft Palate. Hum Mutat 2004; 24: 104-105.

15. Mills JL, Molloy AM, Parle-McDermott A, Troendle J F, Lawrence C, Brody LC, et al. Folate-Related Gene Polymorphisms as Risk Factors for Cleft Lip and Cleft Palate. Birth Defects Research (Part A)2008; 82:636-643.

16. Ali A, Singh SK and Raman R. MTHFR 677TT alone and IRF6 820GG together with MTHFR 677CT, but not MTHFR A1298C, are risks for nonsyndromic cleft lip with or without cleft palate in an Indian population. Genetic Testing and Molecular Biomarkers 2009;13:355-360.

17. Sözen MA, Tolarova MM and Spritz RA. The common MTHFR C677T and A1298C variants are not associated with the risk of non-syndromic cleft lip/palate in northern Venezuela. J. Genet. Genomics 2009; 36: 283-288.

18. Cochran WG. The combination of estimates from different experiments. Biometrics 1954; 10: 101-129.

19. Zintzaras E. Maternal gene polymorphisms involved in folate metabolism and risk of Down syndrome offspring: a metaanalysis. Journal of Human Genetics 2007; 52:943-953.

20. Zintzaras E and Hadjigeorgiou GM. The role of G196A polymorphism in the brain-derived neurotrophic factor gene in the cause of Parkinson's disease: a meta-analysis. J Hum Genet 2005; 50:560-566.

21. Mantel $\mathrm{N}$ and Haenszel W. Statistical aspects of the analysis of data from retrospective studies of disease. J Natl Cancer Inst 1959; 22(4): 719-748.

22. DerSimonian $\mathrm{R}$ and Laird N. Meta-analysis in clinical trials. Control Clin Trials 1986; 7: 177-188.

23. Whitehead A. Meta-analysis of controlled clinical trials. Wiley, Chichester, UK.2002.

24. Egger M, Davey Smith G, Schneider M and Minder C. Bias in meta-analysis detected by a simple, graphical test. BMJ 1997; 315: 629-634.

25. Bax L, Yu LM, Ikeda N, Tsuruta H and Moons KG. Development and validation of MIX: comprehensive free software for meta-analysis of causal research data. BMC Med Res Methodol 2006; 6: 50.

26. Tolarova MM, van Rooij IA, Pastor $M$, van der Put NM, Goldberg AC, Hol F, et al. A common mutation in the MTHFR gene is a risk factor for nonsyndromic cleft and palate anomalies. Am J Hum Gene 1998; 63:A27.

27. Shotelersuk V, Ittiwut $C$, Siriwan $P$ and Angspatt $A$. Maternal 677CT/1298AC genotype of the MTHFR gene as a risk factor for cleft lip. J Med Genet 2003; 40:e64.

28. Van Rooij.A, Swinkels DW, Blom HJ, Ursem N, Steegers E and Steegers-Theuinessen R. Vitamin and Homocysteine Status of Mothers and Infants and the Risk of Nonsyndromic Orofacial Clefts. Amer J Obstet Gynecol 2003; 189: 1155-1160.

29. Chorna LB, Akopyan HR, Makukh HV and Fedoryk IM. Allelic Polymorphisms in the MTHFR, MTR and MTRR Genes in Patients with Cleft Lip and/or Palate and Their Mothers. Cytology Genetics 2011; 45: 177-181.

30. Semiç-Jusufagiç A, Bircan R, Çelebiler O, Erdim M, Akarsu N and Elçioğlu1 NH. Association between C677T and A1298C MTHFR gene polymorphism and nonsyndromic orofacial clefts 
in the Turkish population: a case-parent study. The Turkish Journal of Pediatrics 2012; 54: 617-625.

31. Boyles AL, Wilcox AJ, Taylor JA, Meyer M, Fredriksen A, Ueland PM, et al. Folate and one-carbon metabolism gene polymorphisms and their associations with oral facial clefts. Am J Med Genet A 2008; 146:440-449.

32. Martinelli M, Scapoli L, Pezzetti F, Carinci F, Carinci P, Stabellini G, et al. C677T variant form at theMTHFR gene and CL/P: A risk factor for mothers?Am. J Med Genet 2001;98:357-360.

33. Wong WY, Eskes TK, Kuijpers-Jagtman AM, Spauwen PH, Steegers EA, Thomas CM, et al. Nonsyndromic orofacial clefts: association with maternal hyperhomocysteinemia. Teratology 1999; 60:253-257.

34. Qian X, Lu Z, Tan M, Liu H, and Lu D.Ameta-analysis of association between $\mathrm{C677T}$ polymorphism in the methylenetetrahydrofolate reductase gene and hypertension. European Journal of Human Genetics 2007; 15:1239-1245.

35. Zhang T, Lou J, Zhong R, Wu J, Zou L, SunY, et al. Genetic Variants in the Folate Pathway and the Risk of Neural Tube Defects: A Meta-Analysis of the Published Literature. PLos one 2013;8: e59570.

36. Wu X, Wang X, Chan Y, Jia S, Luo Y, and Tang W. Folate metabolizing gene polymorphisms MTHFR C677T and A1298c and risk for Down syndrome offspring: a meta-analysis. Eur. J. Obstet. Gynecol. Reprod Biol 2013; 167(2): 154-159.

37. Xuan C, Xiao-Yan Bai, Ge Gao, Qin Yang and Guo-Wei He. Association between polymorphism of methylenetetrahydrofolate reductase (MTHFR) C677T and risk of myocardial infarction: A meta-analysis for 8,140 cases and 10,522 ontrols. Archives of Medical Research 2011;42: 677e685.

38. Schürks M, Rist PM and Kurth T. 5-HTTLPR Polymorphism in the Serotonin Transporter Gene and Migraine: A Systematic Review and Meta-Analysis. Cephalalgia 2010; 30(11): 1296-1305.

39. Zintzaras E. C677T and A1298C methylenetetrahydrofolate reductase gene polymorphisms in schizophrenia, bipolar disorder and depression: a meta-analysis of genetic association studies. Psychiatr Genet 2006; 16:105-115.

40. Rai V. Evaluation of methylenetetrahydrofolate reductase gene variant $(\mathrm{C} 677 \mathrm{~T})$ as risk factor for bipolar disorder. Cell Mol Biol 2011; 57: OL1558-OL1566.

41. Wu YL, Ding XX, Sun YH, Yang HY, Chen J, Zhao X, et al. Association between MTHFR C677T polymorphism and depression: An updated meta-analysis of 26 studies. Progress in Neuro-Psychopharmacology \& Biological Psychiatry 2013; 46: 78-85.

\section{Authors Contribution:}

VR - All from Solo Author.

Source of Support: Nil, Conflict of Interest: None declared. 